\title{
ЄВРОПЕЙСЬКІ СТАНДАРТИ ВЗАЕМОДІЇ ОРГАНІВ ПУБЛІЧНОЇ ВЛАДИ \\ З ІНСТИТУТАМИ ГРОМАДЯНСЬКОГО СУСПІЛЬСТВА
}

Лізаковська $\boldsymbol{C}$. В., канд. наук 3 держ. упр., доцент, Військовоморська академія імені Героїв Вестерплатте в Гдині, Польща

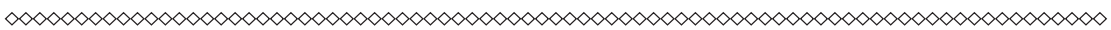

У статті проаналізовано стандарти співпраці влади $i$ громадянського суспільства, визначено сутність, завдання і форми взаємодії органів влади та інститутів громадянського суспільства.

Висвітлено регламентуючі документи Свропейського Союзу щчодо взаємодї органів публічної влади та громадянського суспільства.

Окреслено принщипи та стандарти взаємодї влади та інститутів громадянського суспільства.

Проаналізовано особливості, специфіку та умови ефективної взаємодї̈ громадянського суспільства й органів публічної влади в краӥнах-членах $С C$.

Показано що у більшості краӥн СС законодавство передбачає створення спеціальних органів, які діють на постійній основі, наприклад, консультативні органи з питань захисту прав споживачів та довкілля, охорони здоров'я за участю відповідних інститутів громадянського суспільства, що відіграють ключову роль у процесах прийняття рішень органами публічної влади у визначених їх компетенціями сферах.

Встановлено, щзо ефективною моделлю взаємодії громадянського суспільства і органів публічної влади є співпрачя за умов певного збігу інтересів та ціннісних установок окремих громадян і сочіальних груп з органами публічної влади.

Ключові слова: взаємодія, взаємозв'язок, громадянське суспільство, демократія, державна влада, комунікація, співпраця, управління, иінності. 
Постановка проблеми у загальному вигляді. Громадянське суспільство є невід'ємною частиною громадського, суспільно-політичного, культурного життя країн-членів Європейського Союзу. Рада Європи у Конвенція про захист прав людини і основоположних свобод (стаття 11) гарантує право громадян на зібрання та об'єднання.

3 кінця XX ст. все більше країн прагнуть реалізувати такі принципи демократичного врядування як відкритість влади, участь громадян у суспільно-політичних процесах, відповідальність органів влади перед сувереном (народом), ефективність діяльності, узгодженість дій. Це передбачає формування відповідних інститутів та механізмів, які дозволяють більш ефективно враховувати потреби громадян. В країнах ЄС є нормою та стандартом залучення жителів конкретного населеного пункту до вирішення проблем громади. Крім того, ефективність та якість вирішення великого спектру питань локального значення та реалізація відповідних повноважень органами місцевого самоврядування залежить від взаємодії місцевої влади 3 населенням територіальної громади. Народ як суверен влади згідно з Жаном Боденом є основою держави. В нормативноправових документах ЄС громадяни мають бути поінформовані про всі важливі ініціативи в їх територіальній громаді, ознайомлені 3 планами, які запропонували їх представники на різних рівнях влади та офіційні особи. Більша взаємодія місцевих рад та громадян має гарантувати ефективність прийняття та реалізації раціональних рішень складних завдань, сприятиме поліпшенню місцевих політичних обставин [7].

Встановлено, що сучасні ринкові відносини та в умовах соціальної трансформації, доцільним є залучення нових суб' єктів до реалізації публічних політик, тобто передбачається конструктивна взаємодія інститутів влади на локальному ті національному рівнях і громадського суспільства.

На вітчизняному рівні суспільно-політичні зміни мають відбуватися за участю самих громадян, жителів територіальних громад, які при підтримці та за узгодженням з органами місцевого самоврядування та представницькими органами державної влади на місцях, будуть залучатися до різноманітних ініціатив. 
В країнах Свропейського Союзу поширеним є делегування владою вирішення різного рівня проблеми інститутам громадського суспільства.

Як зазначають науковці Н. Гавкалова, М. Грузд у своїй науковій праці щодо взаємодії органів публічної влади 3 інститутами громадянського суспільства, що вітчизняний досвід взаємовідносин між публічною владою та інститутами громадського суспільства свідчить про відсутність універсальних шляхів ефективної взаємодії означених інституцій, що пов'язано 3 національною специфікою, економічними, політичними та соціальними умовами, які відображають культуру, історію та традиції країни [4, с. 282].

Метою статті є визначення та аналіз європейських стандартів взаємодії органів публічної влади 3 інститутами громадянського суспільства та характеристика можливостей їх імплементації у вітчизняну практику.

Аналіз останніх досліджень і публікацій. Співпраця та взаємодія інститутів громадянського суспільства і владних структур досліджували вітчизняні і зарубіжні науковці такі як В. Войтков, Н. Гавкалова, М. Годзюр, М. Грузд, В. Гуцов, Л. Загайнов, І. Ібрагімова, М. Ільїн, Л. Ільчук, В. Карлов, Г. Колісник, С. Кравченко, T. Крушельницька, А. Куюмджиєва, Н. Ларіна, А. Матвієнко, А. Михненко, Н. Розенблюм, В. Роман, Л. Рубан, Ф. Рудич, С. Ситник, I. Ткаченко, Л. Фугель, Л. Шинелова, І. Шумляєва та інші.

Формулювання цілей статті (постановка завдання). У процесі аналізу нормативно-правової бази та наукових розробок, а також дослідження розвитку й удосконалення взаємодії органів публічної влади з інститутами громадянського суспільства в $\mathrm{CC}$, були сформульовані наступні завдання:

- проаналізувати сутність і специфіку регламентуючих документів Свропейського Союзу щодо взаємодії органів публічної влади 3 громадянським суспільством;

- окреслити засади і стандарти взаємодії влади та інститутів громадянського суспільства;

- вивчити умови і критерії ефективної взаємодії вищезазначених суб'єктів; 
- висвітлити результати вдалої співпраці влади 3 громадськістю на прикладі деяких країн Європейського Союзу.

Виклад основного матеріалу дослідження. Початки взаємодії влади 3 організаціями, які відносять до інститутів громадянського суспільства (об’єднання громадян, ініціативні групи), можна вже від слідкувати в Конвенції Європейської економічної комісії ООН про доступ до інформаиії, участь громадськості у проиесі прийняття рімень та доступ до правосуддя з питань, щзо стосуються навколичнього середовища з 1998 р. та Основоположних принципах статусу громадських організацій у Європі з 2002 р.

Також вже Римськими договорами (1957р.), які вважаються основоположними договорами Європейського Союзу було зафіксовано залучення економічних та соціальних груп інтересів до процесу формування спільного ринку. 3 цією метою був створений Європейський економічний та соціальний комітет, який безпосередньо взаємодіє 3 представницькими органами організацій громадянського суспільства держав-членів Європейського Союзу.

Єдиний Європейський акт 1986 р., який передбачав формування єдиного ринку, а також Маастрихтський договір 1992 р., Амстердамський договір 1997 р. та Ніццький договір 2000 р. закріпили роль та значення Європейського економічного та соціального комітету як консультативного і дорадчого органу в прийнятті рішень керівними інституціями $Є C$ [14, с. 16].

Лісабонський договорів, який вступив в силу після двох років по його підписання, а саме 01.12.2009 р., закладав зміни в демократичному розвитку країн-членів $\mathrm{EC}$, а саме те, що органи влади ї̈х діяльність повинна бути більшпрозорою, процес прийняття рішень - відкритим, тим самим реалізуючи сподівання громадян на відкрите, прецизійне, продуктивне державне управління.

Експерт ОБСС А. Куюмджиєва у своєму дослідженні зазначає, що усвідомлюючи дедалі більше ослаблення довіри до європейських і національних органів влади і відчуження європейців від політичного процесу, Свропейська комісія на початку 2000 р. розгорнула реформу європейського управління, зробивши їі одним зі своїх стратегічних завдань. Нова реформа була спрямована на ISSN 2616-6216. Publ. upr. reg. rozvit. 2020, 8: 422-444 
«Public Administration and Regional Development»

https://pard.mk.ua/index.php/journal

усвідомлення того, що демократичні інститути європейського і національного рівня повинні докласти всіх зусиль, аби «відновити зв'язок» зі своїми громадянами і тим самим підвищити ефективність державного управління [8, с. 16].

Європейська комісія у Білій книзі «Про європейське управління» прописала інструменти посилення громадської участі в політичному процесі та підкреслила необхідність застосування Інтернет-технологій у даному процесі, а саме:

- надавати громадянам в режимі он-лайн актуальну інформацію про підготовку заходів, які заплановано на всіх етапах прийняття рішень;

- встановити та опублікувати стандарти проведення консультацій;

- зміцнити способи комунікації з громадськістю щодо питань загальноєвропейського значення, тим самим даючи громадянам змогу контролювати процес прийняття рішень на всіх його етапах;

- в деяких сферах життєдіяльності розвивати партнерські відносини, які виходять за рамки мінімальних стандартів i зобов'язують комісію проводити додаткові консультації з метою надання більших гарантій відкритості та представництва тих організацій, з якими проводяться подібні консультації [2].

Міжнародна організація економічного співробітництва та розвитку (далі - ОЕСР) визначила три основні стадії відносин між владою і громадянами: інформування, консультації та активна участь (партнерство) [8, с. 27]. Володіння інформацією і усвідомлення нагальності проблем на локальному, національному рівнях передбачає залучення громадян до їх вирішення. Для реалізації даних стадій взаємовідносин необхідні підстави їх розвитку. ОЕСР окреслює передумови розвитку кожної з цих стадій:

- надання інформації та забезпечення доступу до неї вимагає наявності чіткої нормативно-правової бази, сильних суспільних інститутів, суворих наглядових механізмів і суспільства, яке добре знає свої права і діє відповідним чином;

- проведення консультацій у різних країнах практикуються в різній формі - від створення сильної нормативно-правової бази до запровадження неформальних правил і певних практичних методів. 
Забезпечення зворотного зв'язку з громадськістю й отримання відгуків на програмні пропозиції влада може здійснювати різними методами (опитування громадської думки, семінари, громадські слухання, фокусні групи);

- визнання здатності громадянського суспільства самостійно готувати й формулювати програмні пропозиції та отримання від органів влади інформації щодо їхніх реформаторських планів та врахування пропозиції ОГС [8, с. 27-29].

У більшості країн ЄС законодавство передбачає створення спеціальних органів, які діють на постійній основі, наприклад, консультативні органи з питань захисту прав споживачів та довкілля, охорони здоров'я за участю відповідних інститутів громадянського суспільства, що відіграють ключову роль у процесах прийняття рішень органами публічної влади у визначених їх компетенціями сферах.

Як зазначає науковець В. Роман, у деяких країнах $\mathrm{CC}$ законодавство, що регулює діяльність уряду, органів державного управління та держадміністрацій, містить конкретні положення й вимоги щодо проведення публічних консультацій відносно процесу розроблення і прийняття підзаконних актів та інших регуляторних інструментів [10, с. 10].

В літературі з даної проблематики, теоретики i практики окреслюють позитивні аспекти участі громадськості в суспільнополітичних процесах, а саме такі як:

- участь шляхом збору та передачі поглядів різних зацікавлених громадян через ОГС з метою здійснення впливу на процес прийняття політичних рішень;

- довіру та відкритість, чесну взаємодію між політичними силами та суспільством; відповідальність та прозорість як з боку ОГС, так і з боку державних органів на всіх етапах діяльності;

- незалежність та неупередженість ОГС, свободу у прийнятті рішень та діяльності;

- відсутність дискримінації, однакове ставлення до всіх осіб, включаючи представників меншин, соціально незахищених верств, вразливих чи соціально відчужених осіб чи груп, які бажають взяти участь у вирішенні проблем [8]. 
«Public Administration and Regional Development» https://pard.mk.ua/index.php/journal

Нормативно-законодавча база $\epsilon$ основою функціонування громадянського суспільства в державах права, а також гарантує необхідні умови для участі інститутів громадянського суспільства в житті країни.

На основі європейського досвіду, можна запропонувати сфери, в яких доцільно співпрацювати громадськості з органами публічної влади на табл. 1).

Таблиця 1

Пропоновані сфери взасмодії органів публічної влади та громадськості

\begin{tabular}{|c|c|c|}
\hline № & Сфери взаємодії & Характеристика \\
\hline 1. & Якісні доступні послуги & $\begin{array}{ll}\text { - } & \text { якісна освіта } \\
\text { - } & \text { навчання протягом усього } \\
& \text { життя } \\
\text { - } & \text { підтримка та фізичний, } \\
& \text { психічний розвиток дітей } \\
\text { - } & \text { безпека у сфері охорони } \\
& \text { здоров’я } \\
\text { - } & \text { якісні медичні послуги }\end{array}$ \\
\hline 2. & Якісна зайнятість & $\begin{array}{ll}\text { - } & \text { гендерна рівність } \\
\text { - } & \text { баланс між роботою та } \\
& \text { приватною сферою } \\
\text { - } & \text { адекватна мінімальної } \\
& \text { заробітної плати } \\
\text { - } & \text { активна підтримка } \\
& \text { зайнятості } \\
\text { - } & \text { безпечні умови праці } \\
\text { - } \quad \text { гідна праця та економічне } \\
\text { зростання } \\
\text { - здорове, безпечне робоче } \\
\text { середовище } \\
\text { - захист даних }\end{array}$ \\
\hline
\end{tabular}


продовження таблиці 1

\begin{tabular}{|c|c|c|}
\hline 3. & Соціальний захист & $\begin{array}{ll}\text { - } & \text { підтримка людей похилого } \\
& \text { віку } \\
\text { - } & \text { робота з безпритульними } \\
\text { - } & \text { допомога дітям } \\
& \text { малозабезпечених сімей } \\
\text { - } & \text { робота 3 людьми } \\
& \text { обмеженим можливостями } \\
\text { - } & \text { хоспіційна } \\
& \text { (довготривалий догляд за } \\
& \text { хворими); }\end{array}$ \\
\hline 4. & Сталий розвиток громад & $\begin{array}{ll}\text { - } & \text { самоорганізація } \\
\text { - } & \text { самодопомога } \\
\text { - } & \text { соціальна відповідальність }\end{array}$ \\
\hline 5. & $\begin{array}{c}\text { Доступ до належних } \\
\text { житлових умов }\end{array}$ & $\begin{array}{ll}\text { - } & \text { доступність житла для } \\
& \text { безпритульних } \\
\text { - } & \text { підтримка молоді у сфері } \\
& \text { забезпечення житлом } \\
\text { - } & \text { безпечні житлові умови осіб } \\
& \text { у державних закладах опіки }\end{array}$ \\
\hline 6. & Екологія & $\begin{array}{llr}\text { - } & \text { превенція } & \text { екологічних } \\
\text { катастроф } & \\
\text { - } & \begin{array}{l}\text { охорона } \\
\text { середовища }\end{array} & \text { навколишнього }\end{array}$ \\
\hline
\end{tabular}

Аналіз європейських норм дає можливість прослідкувати наступну тенденцію: інститути громадянського суспільства виступають важливим партнером під час прийняття рішень та реалізації публічних політик в країнах-членах $\mathcal{C}$, а також наявність нормативних засад щодо участі громадськості у вищезазначених процесах демонструє потребу i необхідність функціонування нових акторів - представників громадянського суспільства. В документі «Стандарти та практики у країнах-членах Ради Свропи «Участь громадськості у процесі прийняття рішень» від 2016 p., який підготовлено Свропейським центром некомерційного 
«Public Administration and Regional Development»

https://pard.mk.ua/index.php/journal

права, зазначаються такі практичні рекомендації щодо залучення громадськості у процес реалізації публічних політик в країні:

- у процесі прийняття рішень усі зацікавлені сторони мають бути проінформованими та з усіма мають бути проведені консультації;

- інститути громадянського суспільства відіграють вирішальну роль у цьому процесі; вони можуть сприяти участі громадськості, представляти інтереси своїх членів та зацікавлених осіб, постійно інформувати їх про процес прийняття рішень та його результати;

- важливо передбачити своєчасне надання недвозначної та стислої інформації для забезпечення розуміння питань учасниками та надання їм можливості запропонувати більш значущий внесок;

- час, виділений на участь громадськості, повинен визначатися 3 урахуванням проведення відповідних консультацій; практика показує: потрібен не менш ніж 10-денний період для кожного проекту;

- забезпечення зворотного зв’язку для учасників підвищує довіру та посилює залучення;

- регулярне оцінювання процесу участі громадськості для покращення майбутніх процесів та поширення досвіду застосування креативних моделей;

- задля підтримки участі громадськості на всіх етапах політичного процесу використовуються різні інструменти та механізми;

- забезпечення обізнаності громадськості про процес участі у прийнятті рішень;

- процесу участі та залученню громадян сприяють інструменти електронної участі у зручній для використання формі;

- доцільною є розробка докладних посібників для громадян i службовців;

- корисним є проведення тренінгів 3 питань реалізації механізмів участі громадськості;

- важливо запроваджувати гарантії доступу до інформації та проведення консультацій із зацікавленою громадськістю, що мають юридичну силу і включають положення про надання зворотного зв'язку та механізм оскарження в разі виникнення порушень $[15$, с. 49-50]. 
Таким чином, перелік даних рекомендацій показує вагому роль інформаційної складової в процесі взаємодії різних акторів, а також важливість зворотного зв'язку в системі суб'єкт - об'єкт.

Європейський Союз як політично-економічна спільнота має розгалужену систему інституцій і органів. Прийняття рішення вимагає часу, оскільки в $Є С$ важливою $є$ координація дій між законодавчою та виконавчою владою, а узгодження певних кроків залежить від багатогранності співтовариства.

Як зазначає науковець I. Ткаченко, для ЄC така система взаємодії також є корисною, оскільки саме громадянське суспільство дає достатньо легітимності прийнятим рішенням, які стають загальнообов'язковими і для СС загалом, і для окремих його членів зокрема [14, с. 18].

Взаємодія влади та громадянського суспільства повинна будуватися на конкретних засадах, які окреслюють рамки співпраці, принципи діяльності та цінності, на яких взаємовідносини цих суб'єктів. Міжнародна асоціація 3 питань участі громадськості структурно окреслила основопокладаючі цінності, що передбачають активне залучення громадян до управлінських процесів. Варто звернути увагу на такі як:

- участь у процесі прийняття рішень осіб, яких стосується відповідне рішення або які зацікавлені у цьому рішенні;

- залучення учасників до викладення свого бачення формату їхньої участі;

- надання учасникам інформації, необхідної для ефективної участі;

- визнання й обговорення потреб та інтересів усіх учасників, у тому числі осіб, які приймають рішення;

- надання громадськості можливості впливати на рішення;

- доведення до відома учасників, яким чином їх внесок вплинув на рішення [15, с. 7].

Отже, аналіз даних цінностей демонструє конструктивне залучення громадськості процесу прийняття рішень. В країнах ЄC розповсюджена практика громадського бюджету, коли громадяни шляхом голосування самостійно вирішують в який ISSN 2616-6216. Publ. upr. reg. rozvit. 2020, 8: 422-444 
«Public Administration and Regional Development»

https://pard.mk.ua/index.php/journal

спосіб використати фінансові ресурси в своїй громаді - чи на будівництво велодоріжок, чи на будівництво дитячого майданчику, чи на спорудження спеціально відведеного місця для прогулянки 3 домашніми тваринами.

Схематично можна представити взаємодію громадян для вирішення соціаль-економічних проблем різного рівня на Рис.1.

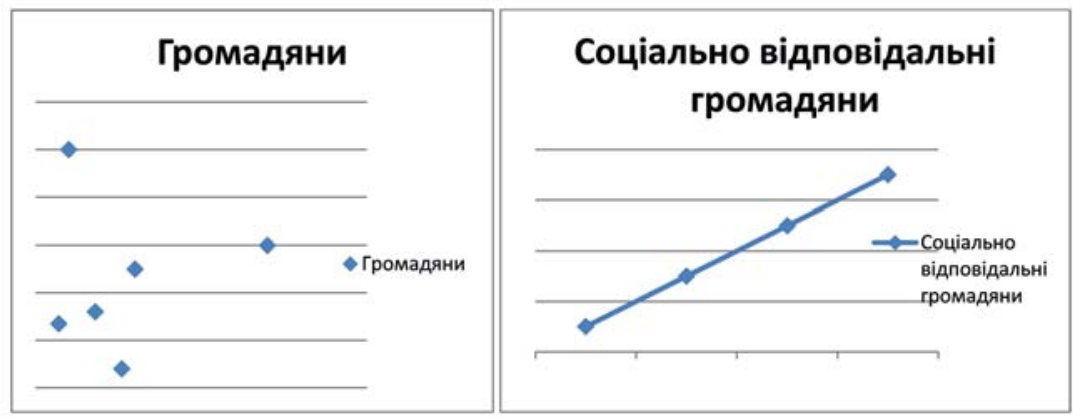

Pис.1. Взаємодія громадян щзодо вирішення сочіаль-економічних проблем різного рівня.

На першій схематичній діаграмі видно, що окремі представники громади займаються вирішенням проблем самостійно, і кожен знаходиться на різному етапі їх вирішення, так як немає злагодженості і єдиного напрямку у подолання нагальної проблеми, що стосується конкретної групи. На другій діаграмі показано взаємодію громадян, які свідомо співпрацюють на основі соціальної відповідальності і партнерства, і ймовірність вирішення проблеми й досягнення конкретної мети є набагато вищою.

В Кодексі належної практики участі громадськості в процесі прийняття рішень, який було ухвалено на Конференції міжнародних неурядових організацій Ради Свропи 1 жовтня 2009 р. вказано наступні принципи взаємодії інститутів громадянського суспільства і органів публічної влади:

- участь шляхом збору та передачі поглядів різних членів інститутів громадянського суспільства і зацікавлених громадян через громадські організації з метою впливу на процес прийняття політичних рішень; 
- довіра як чесна взаємодія між політичними силами та суспільством;

- відповідальність та прозорість як 3 боку громадянського суспільства, так і з боку державних органів на всіх етапах діяльності;

- незалежність інститутів громадянського суспільства, оскільки важливо визнавати дані суб'єкти як вільні й незалежні структури iз власними цілями, рішеннями та заходами [6].

Тобто ці принципи вказують на зрілу позицію суб'єктів взаємодії, яка грунтується на відповідальності за власні дії та довірі учасників відповідного процесу.

Доцільно зазначити, що Білі книги - це документ 3 чіткою структурою, який носить аналітичний характер, й важливою ознакою таких документів є їх відкритий доступ та обговорення громадськістю його пропонованих елементів для впровадження у визначеній сфері. Для Європейської Комісії Білі Книги розробляють експерти та офіційні служби. Якщо Рада ЄC підтримує Білу Книгу, вона може стати програмою дій у відповідній сфері. Серед нещодавніх «Білих Книг» Комісії можна виокремити документи «Адаптація до зміни клімату: в напрямку Європейського Рамкового Плану Дій (2009), «В напрямку більш ефективного контролю ЄС за злиттям» (2014) [1].

Європейська комісія у Білій книзі «Європейське врядування» (Брюссель, 2001 р.) окреслює п’ ять базових засад, які лежать в основі побудови демократичних органів публічної влади та ефективного управління в країні: відкритість, участь, підзвітність, ефективність та злагодженість.

Імплементація даних принципів забезпечить ефективне врядування та демократичну спрямованість діяльності влади. Ці основопокладаючі принципи забезпечують демократичність та легальність політичних процесів у країнах ЄС. але можуть бути застосовані на всіх рівнях влади - світовому, європейському, національному, регіональному і місцевому.

Для Європейського Союзу і його інституцій, дані принципи мають вагоме значення і діяльність європейських органів будується на даних засадах. Варто розкрити кожен з перерахованих принципів: 
«Public Administration and Regional Development»

https://pard.mk.ua/index.php/journal

- відкритість: органи публічної влади, використовуючи комунікаційні інструменти, мають працювати більш відкрито, активно спілкуватися з громадськістю, інформуючи ii про те, які рішення приймаються. В кодексах етики державних службовців в країнах СС звертається увагу на те, що особи, які працюють в органах влади, повинні спілкуватися з громадянами на доступній зрозумілій для них мові;

- партиципація (участь): оперативність, чіткість, актуальність i ефективність програмних заходів в Європейській спільноті залежить від забезпечення широкої громадської участі на кожному етапі прийняття рішення та його реалізації;

- підзвітність: доцільно чітко окреслювати та визначити ролі різних сторін у законодавчому та виконавчому процесах. Про даний принцип в організаціях також писав на початку XX століття французький дослідник Анрі Файоль. Кожна інституція ЄС має представляти загалу свої стратегічні плани та інформувати про хід їх реалізації;

- ефективність: програмні заходи мають бути ефективними, доцільними і показувати досягнутий результат, вирішену проблему, превентивну сторону діяльності на основі чітко поставлених завдань, здійсненого попереднього і поточного контролю;

- злагодженість: публічні політики, які реалізовуються в рамках ЄС мають бути чітко окреслені, узгоджені з суб'єктами взаємодії. Потреба у злагодженості всередині ЄС стає все більш актуальною, оскільки кількість завдань росте і постійно з'являються нові виклики для країн-членів. Національна влада країн та органи місцевого самоврядування держав все частіше бере участь у реалізації політики ЄС за допомогою існування різних доступних програм. Злагодженість вимагає єдиного підходу в управлінні, конструктивного лідерства та відповідальності інституцій ЄС для забезпечення послідовного підходу у складній системі [16, с. 11-12].

Важливим в рамах дослідження $є$ представлення Фундаментальних принципів щодо статусу неурядових організацій в Європі, які були прийняті учасниками багатосторонньої зустрічі, організованої Радою Європи в Страсбурзі в 2002 році. Дані принципи 
описують цілі неурядових організацій, особливості управління та фінансування, а також визначають норми відносин 3 державними органами, а саме вказується на те, що входження компетентної і відповідальної неурядової організації (далі - НУО) до процесу формулювання державної політики збільшує застосовність законодавства і серйозність урядового прийняття рішень. Саме тому НУО повинні заохочуватися брати участь в урядових і квазіурядових механізмах для діалогу, консультації й обміну з метою пошуку шляхів вирішення потреб суспільства. Тобто бачимо чітке заохочення для партнерства та співпраці суб'єктів взаємодії [3]. Далі в тексті документу зазначається, що така участь не повинна ні гарантувати, ні усувати урядові субсидії, контракти чи пожертви індивідуальним НУО чи їхнім групам; консультування не повинно розглядатися урядами як засіб поглинання НУО через сприйняття урядових пріоритетів. Це свідчить про конструктивні взаємовідносини органів публічної влади з недержавними організаціями. Крім того, урядові органи можуть працювати з НУО для досягнення цілей державної політики, але не повинні намагатися заволодіти ними чи змусити їх працювати під своїм контролем. Це свідчить про свободу об'єднань громадян для вирішення конкретного завдання без тиску влади. Недержавні організації також повинні демонструвати елементи співпраці, оскільки уряди повинні з добровільними самоврядними організаціями також консультуватися під час написання проектів первинного i вторинного законодавства, що зачіпає статус, фінансування чи сфери діяльності цих організацій» [3].

Європейські стандарти правового забезпечення функціонування інститутів громадянського суспільства визначені та представлені у Рекомендації CM/Rec (10.10.2007 р.) Комітету Міністрів Ради Свропи державам-членам. У даному документі міститься вимога про безумовне дотримання права неурядових організацій на участь у прийнятті рішень органами державної влади. Вказано, що урядові та квазіурядові органи усіх рівнів повинні забезпечувати ефективну участь неурядових організацій без дискримінації в обговоренні та консультаціях щодо завдань і рішень у сфері державної політики. Така участь має забезпечувати свободу висловлювання різноманітних ISSN 2616-6216. Publ. upr. reg. rozvit. 2020, 8: 422-444 435 
«Public Administration and Regional Development»

https://pard.mk.ua/index.php/journal

думок, поглядів осіб щодо функціонування суспільства. Сприяння такій участі та співпраці повинно включати належне розкриття публічної інформації або доступ до такої інформації. Консультації 3 неурядовими організаціями мають бути обов'язковими у межах підготовки проектів законодавчих актів будь-якого рівня, які впливають на статус неурядових організацій, їх фінансування або сфери діяльності [9].

Варто підкреслити, що органи місцевого самоврядування маючи свій власний бюджет та дотації, субвенції від держави в країнах ЄС оперативно намагаються вирішувати проблеми і залучають громадськість до цього процесу, оскільки більшість проблемних ситуацій, які впливають на життєдіяльність окремого громадянина, громади, торкаються питань, які частково чи повністю лежать у межах компетенції місцевого самоврядування.

У звіті Генерального Секретаря Ради Європи 2015 р. також окреслено принципи ефективного управління, такі як відкритість $і$ прозорість, інновації та відкритість для змін і відповідальність.

Відкритість та прозорість означає, що:

- рішення приймаються та виконуються відповідно до правил і положень законодавства;

- громадськість має доступ до всієї інформації, яка не є обгрунтовано конфіденційною;

- інформація про рішення, їх впровадження та результати має бути доступною громадськості.

Тобто знову підкреслюється необхідність представлення інформації, даних, результатів громадськості.

Інновації та відкритість для змін вказують на наступне:

- здійснюється пошук нових, ефективних способів вирішення проблем та поліпшення результатів;

- випробовуються та застосовуються сучасні методики надання послуг;

- створюється клімат, сприятливий для змін.

- відповідальність органів державної влади передбачає, що:

- усі особи, що приймають рішення, несуть відповідальність за свої рішення; 
- рішення є обгрунтованими, знаходяться під контролем та можуть бути причиною призначення покарання;

- існують засоби правового захисту стосовно адміністративних порушень та неправомірних рішень [15, с.15].

Умовою ефективної взаємодії інститутів громадянського суспільства та органів публічної влади в Європейській спільноті чітко визнано краще залучення громадськості шляхом адекватного інформування громад. Інформація має бути представлена у вигляді, адаптованому до місцевих потреб, та бути доступною усіма офіційними мовами. Інформаційні та комунікаційні технології виконують важливу роль у цьому процесі. Для забезпечення кращого партнерства на різних рівнях додаткові заходи на рівні ЄС необхідні у наступних випадках:

- залучення громадськості у формування політики: брати до уваги регіональний та місцевий досвід при розробці політики; забезпечити встановлення систематичного діалогу з європейськими та національними об'єднаннями регіональних і місцевих урядів;

- більша гнучкість $є$ необхідною, оскільки різноманітність ситуацій на місцях часто унеможливлює встановлення єдиного для Союзу набору правил, без надмірного ускладнення законодавства;

- загальна злагодженість політики передбачає увагу до територіальних відмінностей у таких галузях, як транспорт, енергозабезпечення та захист навколишнього середовища;

- участь громадянського суспільства забезпечується наданням громадянам можливості висловитися з питань, що їх хвилюють, а також можливості забезпечити свої потреби. Громадські організації мобілізують населення та підтримують, у тому числі, тих, хто страждає від дискримінації. Вони діють як превентивні органи [16, c. 12-15].

Як зазначають Н. Гавкалова і М. Грузд, взаємодія громадянського суспільства та держави базується на обгрунтованому розподілі компетенцій серед соціальних груп за наявних легальних каналів впливу на діяльність держави 3 метою уникнення монополізації влади й підкреслюють, що дана система $є$ ефективною тільки за відповідності державної влади наступним вимогам: 
«Public Administration and Regional Development»

https://pard.mk.ua/index.php/journal

- влада, забезпечуючи права і свободи громадян, може бути ефективною тільки тоді, коли гарантує ОГС подолання розбіжностей інтересів та цілей груп;

- сфера впливу влади обмежена настільки, що громадянське суспільство може самостійно реалізувати свої ініціативи та здійснювати діяльність з реалізації суспільних інтересів громадян;

- правова сфера охороняє певні зони свободи громадян від втручання держави, при цьому держава не порушує встановлені правові норми [4, с. 283].

Науковець Л. Ільчук доводить, що взаємовідносини між суспільством, що рухається до звання громадянського, і держави, що претендує на статус правової, соціальної, покликані забезпечувати:

- для людини - утвердження іiі самоцінності в діапазоні від суспільної думки до предметних правових норм, створення достатньої законодавчої основи для реалізації політичної свободи, соціальних гарантій і справедливості, для захисту від чиновницької сваволі і соціальної стихії;

- для суспільства - рівну правову захищеність усіх його соціальних прошарків з боку держави, безумовну перевагу основ, що консолідують у громадському житті його безконфліктність, структурованість і політичну упорядкованість, режим громадянського миру та злагоди, загальний захист суспільства як цілісного, соціально диференційованого, саморегулюючого організму від негативного впливу зовнішніх чинників i, нарешті, контроль суспільства над державою, прозорість і підзвітність діяльності його структур;

- для держави - адекватне втілення прав людини в юридичні норми і в механізми захисту цих прав, що виключає політичний волюнтаризм владних структур, соціальну і національну дискримінацію, гарантує панування права в усіх сферах життя, формування оптимальної, самодостатньої системи державно-політичних інститутів, створення умов для продуктивної законотворчої діяльності, результати якої відповідають інтересам людини і втілюються в повсякденному житті через потужний виконавчий механізм усіх гілок влади [5]. 
Варто підкреслити, що інститути громадянського суспільно співпрацюють як з окремими громадянами на локальному рівні, так 3 органами державної влади та місцевого самоврядування на національному, а для залучення додаткових ресурсів налагоджують співпрацю з бізнес-структурами в напрямку створення благодійних фондів як альтернативних джерел фінансування соціальної, культурної, екологічно та інших сфер зображено на Рис 2.

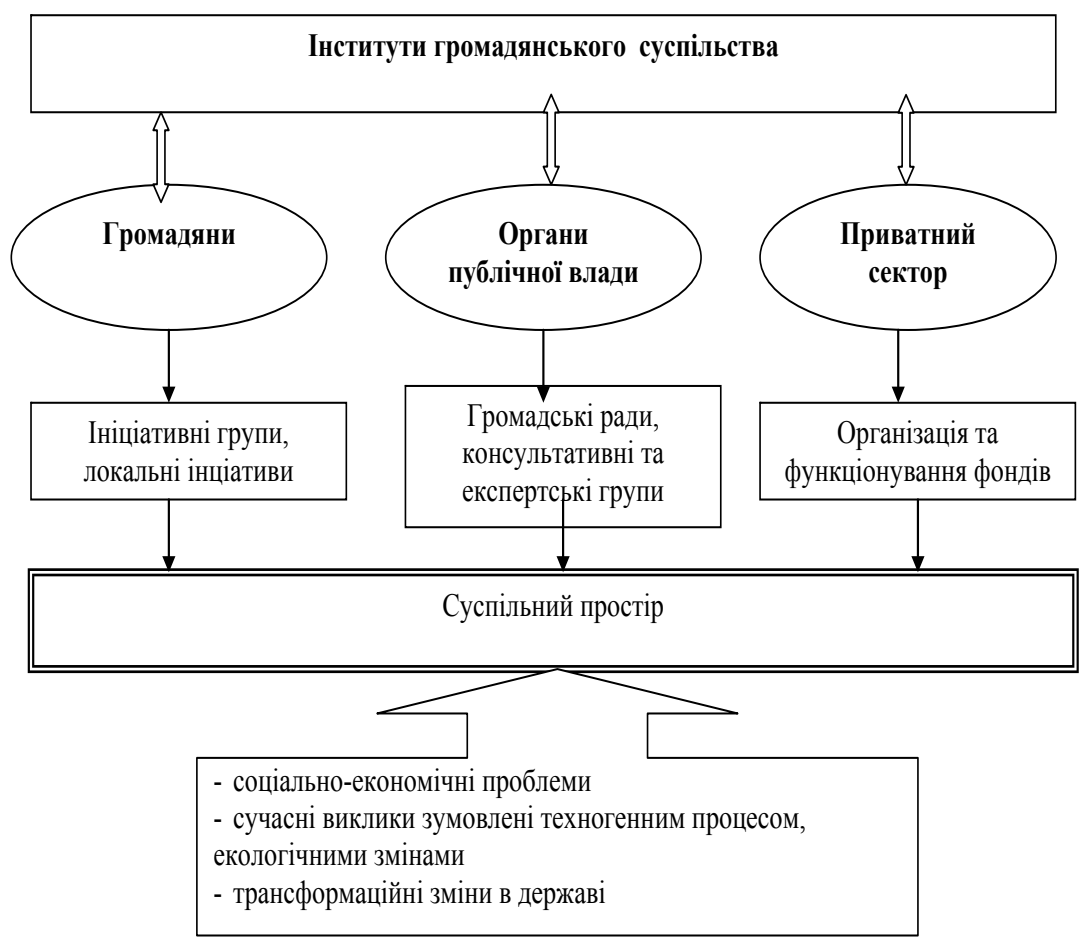

Pис 2. Суб'єкти взаємодії та форми їх співпраці у сфері взаємовідносин з громадськістю 
«Public Administration and Regional Development»

https://pard.mk.ua/index.php/journal

Європейський досвід свідчить, що на сучасному етапі розвитку суспільства органи влади усіх рівнів мають взаємовигідно та ефективно співпрацювати 3 громадськістю. Тільки у взаємодії 3 інститутами громадянського суспільства владні структури зможуть оперативно реагувати на нові виклики, що раптово зявляються в соціумі.

Висновки. Доцільність та обов'язковість залучення громадськості органами державної влади та місцевого самоврядування в Свропейському Союзі до чітко окреслених етапів прийняття рішення та реалізації публічних політик визначено в національному законодавстві країн-членів Свропейської спільноти.

Важливими елементами успішного процесу щодо залученні громадськості до формування політики є: інформування громади, консультації 3 експертами та представниками громадськості, партиципація громадськості у процесі прийняття рішень.

Важливою умовою ефективної та конструктивної взаємодії добровільних самоврядних організацій та органів публічної влади визначено: залучення громадськості шляхом їх інформування та представлення даних за допомогою різноманітних комунікативних інструментів. Інформація має бути представлена у вигляді, адаптованому до місцевих потреб, та бути доступною усіма офіційними мовами.

На сьогодні не існує ідеальної, тобто універсальної моделі взаємовідносин органів публічної влади та громадськості в країнах ЄС. Але визначено необхідні елементи такої взаємодії, а саме наявність досконалої нормативно-правової бази (легіслаційний елемент), відкритість та прозорість влади, врахування громадської думки та позиції громади, залучення громадян до участі в реалізації публічних політик.

Таким чином, взаємовідносини органів публічної влади 3 інститутами громадянського суспільства в рамках $\mathrm{CC}$ можна окреслити як партнерські, але потрібно підкреслити, що громадські організації не можуть підміняти собою владні структури, а органи влади, делегуючи їм частину повноважень, підтримувати та заохочувати до вирішення нагальних проблем у суспільстві.

Стаття надійшла до редакції: 22.03.20 


\section{EUROPEAN STANDARDS OF INTERACTION BETWEEN PUBLIC AUTHORITIES AND CIVIL SOCIETY ORGANIZATIONS}

Svitlana Lizakowska, PhD in Public Administration, Associate Professor of the Department Polish Naval Academy, Gdynia, Poland

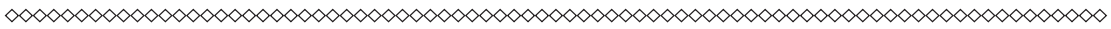

Essence, main features, functions, goals and forms of interaction between authorities and civil society organizations are defined in the article. The concept of mutual understanding and effective cooperation between local authorities and civil society at the development, implementation and monitoring of both national and local policies, which are within the direct interests of public good, is one of the basic characteristics for a modern democratic and developed state serving its citizens.

EU regulatory documents on interaction between public authorities and civil society organizations have been investigated. An overview of laws in European countries demonstrates an existing general framework for public participation and outlines important elements that may be used as recommendations for other countries. The need for local authorities to involve citizens in certain elements of settlement governance is directly stated in the constitution, laws and regulations of European countries.

In many EU countries, legislation provides for the establishment of permanent advisory bodies on protection of consumers and the environment, health protection involving relevant civil society institutes. In some areas, such bodies assemble government officials and CSOs. They possess legally stated authority to participate in governance and to monitor the implementation of policy in a particular sphere.

Values, principles and standards of interaction between government and civil society organizations are considered. The interaction between civil society and state is based on a justified distribution of competences among social groups with available legal channels influencing activities 
«Public Administration and Regional Development» https://pard.mk.ua/index.php/journal

of a state in order to avoid monopolization of power.

Peculiarities, specifics and conditions for effective interaction between civil society organizations and public authorities are analyzed. Key elements of success at engaging citizens in public policy-making are: informing a community, consulting with experts representing public, public participation in decision-making, local self-governance decisions.

It is proven that the most optimal model of relations between civil society and state is recognized to be cooperation in conditions of certain coincidence at interests and values of individual citizens and social groups with public authorities.

Basic principles and forms of interaction between civil society organizations and public authorities in developed countries of Europe are defined. Developed democratic countries have experience at interaction between authorities and public and they use its various forms and methods.

Foreign experience proves that at the current stage of social development, authorities at all levels must cooperate closely and mutually with public. Together with public only can authorities solve common social problems.

Keywords: interaction, interconnection, civil society, democracy, public authority, communication, cooperation, governance, values.

\section{Received: 22.03 .20}

\section{References}

1. Bila knyga jak dokument derzavnoji polityki. (2016). [White Paper as a Dokumetn od Public Policy]. Evropejskyj informacijno-doslidnickyj centr. Kyiv. [in Ukrainian].

2. European Governance a White Paper. Retrieved from: https://ec.europa.eu/commission/presscorner/detail/en/DOC_01_10.

3. Fundamentalni pryntsypy shchodo statusu neuriadovykh orhanizatsii v Yevropi. (2002). [Fundamental principles for the status of non-governmental organizations in Europe]. Strasburh. Retrieved from: https://zakon.rada.gov.ua/ laws/show/994 209. 
4. Havkalova N., Hruzd M., (2014). Vzaiemodiia orhaniv publichnoi vlady ta instytutiv hromadianskoho suspilstva [Interaction between public authorities and civil society institutions]. Aktualni problemy ekonomiky. №10 (160). - Kyiv: Nats. akad. upr. [in Ukrainian].

5. Ilchuk L. I., (2014). Rol hromadianskoho suspilstva u protydii koruptsii ta mekhanizmy spivpratsi z orhanamy derzhavnoi vlady [The role of civil society in combating corruption and mechanisms for cooperation with public authorities]: navch.-metod. materialy / L. I. Ilchuk, N. B. Larina, L. M. Fuhel. Kyiv: NADU [in Ukrainian].

6. Kodeks kraszczych praktyk uczasti gromadskosti u procesi pryjniatia riszen. (2009). [Code of the Best Practices for Public Participation in the Decision-making Process]. CONF/PLE(2009)CODE1. Retrieved from: https:// rm.coe.int/16802eeddb.].

7. Manifesto for a new urbanity. European Urban Charter II. (2011). Retrieved from: https://5cidade.files.wordpress.com/2011/06/urban-charter_ en.pdf.

8. Mizhnarodna praktyka zakhodiv, spriamovanykh na zmitsnennia doviry mizh derzhavoiu ta orhanizatsiiamy hromadianskoho suspilstva [International practice of confidence-building measures between the state and civil society organizations]: Doslidzhennia. Proekt na zamovlennia Koordynatora proektiv OBSIe v Ukraini Albeny Kuiumdzhyievoi. Retrieved from: www/osce.org/ ukraine.

9. Rekomendatsiia Komitetu Ministriv Rady Yevropy (shchodo stvorennia ta diialnosti neuriadovykh orhanizatsii) vid 10 zhovtnia 2007 r. [Recommendation of the Committee of Ministers of the Council of Europe (on the establishment and operation of non-governmental organizations)]. Retrieved from: http://zakon2.rada.gov. ua/laws/show/994_937/ card2\#Card.

10. Roman V., (2016). Modeli detsentralizatsii vlady krain Yevropeiskoho Soiuzu [Models detsentralizatsii vlady krain Yevropeiskoho Soiuzu]. Teoriia ta praktyka derzhavnoho upravlinnia. 2 (53). - Kyiv: KhRIDU NADU [in Ukrainian].

11. Rouban L., (1999). Citizens and the New Governance. Beyond New Public Management. - Tokyo: IOS Press Ohmsha.

12. Shumliaieva I. D., (2019). Rozvytok vzaiemovidnosyn orhaniv publichnoi vlady ta hromadian na mistsevomu rivni v umovakh formuvannia pravovoi derzhavy [Development of relations between public authorities and citizens at the 
«Public Administration and Regional Development»

https://pard.mk.ua/index.php/journal

local level in the conditions of formation of the rule of law]. Retrieved from: http://nbuv.gov.ua/UJRN/dums_2019_2_21.

13. Shyneleva L.T., (2002). Obschestvennye nepravytel'stvennye orhanyzatsyy y vlast [Public non-governmental organizations and authorities]. Moscow: Yzdatel'sko-torhovaia korporatsyia «Dashkov y Ko» [in Russia].

14. Tkachenko I., (2015). Hromadianske suspilstvo i Yevropeiskyi Soiuz: funktsionuvannia y spivpratsia [Civil society and the European Union: Functioning and cooperation]. Retrieved from: http://veche.kiev.ua/journal/4544/.

15. Uchast hromadskosti $\mathrm{v}$ protsesi pryiniattia rishen. Ohliad standartiv ta praktyk u krainakh - chlenakh Rady Yevropy [Public involvement in decision-making. Review of Council of Europe standards and practices].Strasburh. Retrieved from: ecnl.org > uploads > 2016/08 > Overview-of-participationstandards_Ukr.

16. Yevropeiske vriaduvannia. Bila knyha. Komisiia yevropeiskykh spivtovarystv [European governance. White book. Commission of the European Communities]. Briussel. 25.7.2001. COM(2001) 428 ostatochna redaktsiia. Retrieved from: https://pravo.org.ua/files/konstutyc/WHITE_BOOK_UKR_REV.pdf.

\section{Відомості про автора / Information about the Authors}

Лізаковська Світлана Володимирівна: Військово-морська академія ім. Героїв Вестерплатте, вул. Шмідовіча 69, Гдиня, 81-103, Республіка Польща.

Svitlana Lizakowska: Polish Naval Academy, str. Inżyniera Jana Śmidowicza 69, Gdynia, 81-103, Poland.

ORCID.ORG/0000-0002-1524-2673

E-mail: svema84@mail.ru 